\title{
Effect of hydrophobicity of Gas Diffusion Layer in Calcium Cation Contamination in Polymer Electrolyte Fuel Cells
}

\author{
Md Aman Uddin ${ }^{\mathrm{a}, \mathrm{b}^{*}}$, Jaehyung Park ${ }^{\mathrm{a}, \mathrm{b}}$, Leonard Bonville ${ }^{\mathrm{b}}$, and Ugur Pasaogullari ${ }^{\mathrm{a}, \mathrm{b}}$ \\ a Department of Mechanical Engineering, \\ ${ }^{\mathrm{b}}$ Center for Clean Energy Engineering, \\ University of Connecticut, Storrs, CT 06269, USA \\ *Corresponding Author: aman.uddin@engr.uconn.edu
}

\begin{abstract}
To understand the effect of gas diffusion layer (GDL) in cation contamination in polymer electrolyte fuel cells (PEFCs), three membrane electrode assembly (MEA) configurations were soaked in a cationic $\left(\mathrm{Ca}^{2+}\right)$ solution, with the major difference being whether catalyst coated membrane (CCM) was exposed (either completely or partially) to the cationic solution or separated by the GDL and gasket. Significant performance drop was observed with the CCMs which were in direct or partial contact with the $\mathrm{Ca}^{2+}$ solution, however, no significant change in performance occurred where the CCM was separated by the GDL and gasket. It seems that the GDL acts as a barrier to the transport of $\mathrm{Ca}^{2+}$ solution into the CCM, possibly due to very highly hydrophobic nature of the GDL, especially in the microporous layer (MPL) next to the catalyst layers. When a wetting agent was added to the cationic solution to increase the wettability of the GDL, a drop in the performance was observed which verified that the hydrophobicity of the GDL and the MPL hindered the transport of $\mathrm{Ca}^{2+}$ solution into the CCM.
\end{abstract}

Keywords: Polymer electrolyte fuel cell, Cation contamination, Gas diffusion layer, Microporous layer, Hydrophobicity, Wetting agent 


\section{Introduction}

As polymer electrolyte fuel cells (PEFCs) get nearer to commercialization, durability issues due to impurities are becoming a greater concern. Cationic impurities get introduced into PEFC from either the ambient air or from the corrosion of stack and balance of plant (BoP) components [1-4]. If cationic impurities enter the ionomer (either in the membrane or in the catalyst layer) of PEFCs, cations replace protons on the sulfonic acid side chain resulting in reduced ionic conductivity and water content [5-13], as well as lowering gas permeability through the ionomer [17-16] and decrease fuel cell performance [17-19].

Okada and his colleagues experimentally investigated the effect of various cations through ex-situ contaminating the membrane before the fuel cell testing [8-13] and reported that except $\mathrm{Li}^{+}$, all foreign cations have higher preference over proton in the membrane. They reported that oxygen reduction reaction (ORR) is suppressed by cation contamination either due to lowered oxygen gas transport or due to suppressed charge transfer reactions by cations $[12,15]$. Durst et al. reported that the interactions between metal cations and the Pt surface enhance the adsorption of oxygen-containing species and therefore negatively impact the ORR kinetics [16]. Moreover, cations can act as a catalyst for peroxide radical formation resulting membrane degradation [3, 20]. Li et al. investigated $\mathrm{Fe}^{3+}$ and $\mathrm{Al}^{3+}$ contamination through in-situ injection in the air stream of the fuel cell that caused significant cell performance degradation due to the formation of pinholes in the membrane through Fenton's reaction and reduced ORR kinetics [3].

In our previous studies, we investigated effect of various metal cations $\left(\mathrm{Na}^{+}, \mathrm{K}^{+}\right.$, $\left.\mathrm{Mg}^{2+}, \mathrm{Ca}^{2+}, \mathrm{Ni}^{2+}, \mathrm{Ba}^{2+}, \mathrm{Al}^{3+}, \mathrm{Cr}^{3+}, \mathrm{Fe}^{3+}\right)$ with a combination of various anions $\left((\mathrm{Cl})^{-}\right.$, $\left.(\mathrm{OH})^{-},\left(\mathrm{ClO}_{4}\right)^{-},\left(\mathrm{CO}_{3}\right)^{2-},\left(\mathrm{SO}_{4}\right)^{2-}\right)$ by in-situ injection into the air stream of an operating 
fuel cell [21-27] as well as ex-situ contaminating the membrane electrode assembly (MEA) $[19,28]$. After the screening studies with various cations, one contaminant $\left(\mathrm{Ca}^{2+}\right)$ was selected for in-depth studies that was not well investigated and abundant in the nature.

We have studied the effects of $\mathrm{Ca}^{2+}$ as a fuel cell contaminant at various operating conditions and contamination levels [21]. Various concentration of $\mathrm{CaSO}_{4}(1.14 \mathrm{mM}$, $2.85 \mathrm{mM}$, and $5.7 \mathrm{mM}$ ) were introduced in the air stream of the fuel cell and tested with three different current densities $\left(0.2 \mathrm{~A} / \mathrm{cm}^{2}, 0.5 \mathrm{~A} / \mathrm{cm}^{2}\right.$, and $\left.1 \mathrm{~A} / \mathrm{cm}^{2}\right)$. Higher concentration of $\mathrm{Ca}^{2+}$ resulted higher performance loss, and precipitation of $\mathrm{CaSO}_{4}$ was found at the contact regions between the gas diffusion layers (GDL) and cathode flow field. Low current density operation resulted in higher precipitation, even clogging the flow channels resulting in high mass transport loss. We also investigated how cations affect in the through plane direction of the cell and the distributed cell performance using a segmented cell [22] and a multilayer membrane cell [23], respectively. In all the tests, depending on the operating conditions, water management significantly affected contamination by cations which resulted in salt precipitation causing serious mass transport losses. Salts mostly deposited on the flow field and the GDL surface and some salts penetrated into the GDL, but there was no deposit inside the microporous layer (MPL). It seems that the GDL and the MPL were acting as a barrier for the contaminant aerosol into the air stream of the fuel cell. This study was intended to verify this hypothesis.

In this technical contribution, we have specifically investigated the role of GDL in uptake of cationic contamination by varying the presence. We used three membrane electrode assembly (MEA) configurations with the major difference being whether 
catalyst coated membrane (CCM) was exposed to the cationic solution or separated by the GDL and gasket. To understand the cation contamination mechanism, this is the first ex-situ contamination test in our group compared to our previous studies [21-27]. The next sections provide the experimental details and the discussion of the results.

\section{Experimental}

The details of the experimental setup and the test procedure were described in elsewhere [21-26]. Briefly, $25 \mathrm{~cm}^{2}$ active area identical cells were tested in a fuel cell test station (Teledyne MEDUSA RD, TELEDYNE Energy Systems, Inc., MA) interfaced with a Scribner 890C load box (Scribner Associates Inc. NC, USA). The membrane electrode assembly (MEA) was prepared with a catalyst coated membrane (CCM) with a

Pt loading of $0.4 \mathrm{mg} \mathrm{cm}^{-2}$ both in the anode and the cathode catalyst layers (GORE® PRIMEA® Membrane Electrode Assemblies, GORE, PRIMEA and design are trademarks of W. L. Gore and Associates, Elkton, MD) and two Freudenberg C4 (Freudenberg FCCT SE \& Co. KG, Germany) gas diffusion layers (GDLs). The Freudenberg GDL consists of carbon paper GDL and microporous layer (MPL) with total thickness of $255 \mu \mathrm{m}$.

Similar to the previous studies [21-23, 26-28] Calcium Sulfate, $\mathrm{CaSO}_{4}(99.99 \%$ pure, Sigma-Aldrich ${ }^{\circledR}$, St. Louis, MO, USA) was used as the contaminant. The contaminant solution was prepared from a solution of $0.9 \mathrm{mM} \mathrm{CaSO} 4$ and $29.1 \mathrm{mM}$ $\mathrm{H}_{2} \mathrm{SO}_{4}$. To conduct the role of GDL in cation transport, three different MEA configurations were used with the major difference being whether the sealing gaskets and/or the gas diffusion layers (GDL) were included in the soaked assembly in various tests. Figure 1 and Table 1 show all configurations used to soak the MEA in contaminant solution. 
In method $\mathrm{A}$, only the catalyst coated membrane (CCM) was contaminated by soaking in cationic solution for 24 hour before assemble the cell. Then the contaminated CCM was used to build the cell, and the cell was conditioned overnight at constant voltage $(0.6 \mathrm{~V})$ with cell temperature of $80^{\circ} \mathrm{C}, \mathrm{H}_{2}$ /Air stoichiometric flow of $2 / 2$, anode/cathode relative humidity $(\mathrm{RH})$ of $100 \% / 75 \%$, and the cell was run overnight until a stable performance was achieved. After conditioning, polarization curves are measured with similar conditions.

In all other methods (B-F) shown in Fig. 1 and Table 1, CCMs were used to build the cells and the cells were conditioned. Then the cells were disassembled and the MEA configurations were soaked in contaminant solution. In method B, The MEA was soaked in contaminant solution in a way that portion of the CCM (outside the GDL) was in direct contact with the $\mathrm{Ca}^{2+}$ solution. In method $\mathrm{C}$, the $\mathrm{CCM}$ was not in direct contact with the solution being separated by both the GDL and a gasket. Only way to enter the solution to the CCM was diffusion through the GDL. In method D and E, soaking configuration was similar to method $\mathrm{C}$ and only the change was the addition of a wetting agent to the $\mathrm{Ca}^{2+}$ solution. Method F was also similar to method $\mathrm{C}$, but it soaked in a solution with the wetting agent only to assess the effect of the wetting agent. Polarization curve was also measured for an as-received CCM which is termed as common baseline.

In method D and E, wetting agent was used to increase the wettability of the GDL and to verify that the GDL wettability was the controlling factor in transport of cation solution. Four compounds were tested as the wetting agent: Triton-X-100 (Tri), isopropanol (IPA), ethanol and methanol, and all were acquired from Sigma-Aldrich (St. Louis, MO, USA). Wettability of the GDL and the CCM were measured by the sessile 
drop method. The ratio of the drop height and width were used for a measure of wettability.

After the test, several MEAs were examined using scanning electron microscope (SEM) (FEI Quanta 250, FEI, Hillsboro, OR, USA) and energy dispersive X-ray spectroscopy (EDX). The cross section samples of the CCMs were prepared using either freeze fracture.

\section{Results and Discussion}

Figure 2a shows the polarization curves obtained immediately after soaking in foreign cation solution with all the configurations shown in Figure 1. For comparison, a reference uncontaminated MEA performance is also included in Figure 2a. Data clearly indicate that, the foreign cation uptake controls the cell performance, and it strongly depends on the soak configuration. Methods A and B showed significant performance drop due to $\mathrm{Ca}^{2+}$ solution in comparison to other configurations, and while comparing the performance with Method A and Method B, Method B showed less performance loss than that of Method A, even the soaking time of Method B was 100 hours, more than 4 times higher than method A (24 hours). The major difference in Method A and Method B was that most of the active area was covered with the GDL in Method B, however there was still portions of the catalyst layer surface that was exposed to cation solution. When the CCM was soaked with Method $\mathrm{C}$ and a soaking time of 100 hours, there was no significant performance loss even with respect to base line performance. In Method C, the area outside the GDL was covered with a gasket; therefore no part of the MEA was directly exposed to the contaminant solution.

The cell performance loss due to contamination can also be visualized through the power density plot as a function of current density (Figure 2b). Compared to the baseline, 
maximum power density decreased by $82 \%$ in Method A, and 54\% in Method B, and minimal change is observed with Method $\mathrm{C}(\sim 6 \%)$, therefore we concluded that the CCM in Method $\mathrm{C}$ was not contaminated by cation solution. To contaminate the CCM in Method C, cation needs to pass through the GDL, hence we argue that the GDL acts as a barrier to the transport of foreign cations $\left(\mathrm{Ca}^{2+}\right)$ into the $\mathrm{CCM}$, possibly due to very highly hydrophobic nature of the GDL, especially in the MPL next to the catalyst layers. For sake of clarity, Method B MEA (randomly selected) was subjected to cross sectional SEM and EDX analysis to ensure the availability of calcium ion in the membrane. Figure 3 shows a representative SEM image of cross section of CCM and EDX of elemental spectrum of the whole image, and it clearly shows the presence of calcium inside the CCM.

The configuration $\mathrm{C}$ resembles the transport phenomena inside a fuel cell most closely. In an operating fuel cell, the cationic solution cannot enter into the CCM due to hydrophobic nature of GDL. To verify that the GDL wettability was the controlling factor, it was decided to increase the wettability of the GDL by adding a wetting agent in the soak solution that contains the cationic impurity. We tested four compounds as the wetting agent: Triton-X (Tri), isopropanol (IPA), ethanol, and methanol, and measured the wettability of a virgin GDL with $1 \%$ of these compounds in DI water using sessile droplet method. Figure 4a shows a sessile droplet showing the characteristic dimensions of the droplet. The ratio of minor axis (L2) to major axis (L1) represents the wettability of the GDL. By convention, the GDL is defined as hydrophilic when the ratio becomes less than $1 / 2$. Figure 4 (b-c) shows L2/L1 ratio of $1 \%$ of all the wetting agents on GDL and MPL surface. Among the wetting agents the Triton-X worked the best, but $1 \%$ Triton-X in DI water was not sufficient to render the GDL hydrophilic. 
To optimize the concentration, various concentrations of Triton-X, namely 1,5 , 10 , and $20 \%$ (by volume) in DI water were used in the sessile droplet experiment, for both sides of the GDL (Fig. 5(a-b)). More than 10\% Triton-X was required to render both side of the GDL hydrophilic. However, it was found that 5\% Triton-X in DI water dissolved and detached the catalyst layer (CL) from the surface of the CCM (Fig. 5c) rendering this composition unsuitable.

In the case of alcohols as wetting agent, the isopropanol showed lowest L2/L1, hence the optimization were carried out with isopropanol at various concentrations, namely 15, 25, and 35\% (by volume) in DI water for both sides of the GDL (Figure 6(ab)). It was found that more than $25 \%$ isopropanol in DI water was necessary to render both sides of the GDL hydrophilic (Fig. 6c).

To check if IPA also caused similar degradation on the catalyst layer (i.e. dissolution and detachment from the membrane), CCMs were soaked in different concentrations of isopropanol at $25^{\circ} \mathrm{C}$ as well as $80^{\circ} \mathrm{C}$ for 24 hours, since the cells were tested at $80^{\circ} \mathrm{C}$. All resulting images are presented in Figure 7 . At $25^{\circ} \mathrm{C}, 30 \%$ IPA dissolved and detached the catalyst layer from the CCM while no change occurred for 10\%-20\% IPA. However at $80^{\circ} \mathrm{C}, 20 \%$ IPA detached the catalyst layer from the CCM. No change was seen for $10 \%$ and $15 \%$ IPA. Even after drying the GDL, which was soaked in $15 \%$ IPA at $80^{\circ} \mathrm{C}$ for 24 hours, MPL remained hydrophilic (Fig. 8). Therefore, $15 \%$ IPA was selected as a wetting agent, although there was some concern that at this concentration IPA itself might be a contaminant. Previous testing has shown that the performance loss due to IPA was recoverable where IPA was introduced into the air stream of the cell, albeit at lower concentrations [29]. Since the MEA was soaked in a higher concentration IPA solution in our case, the effect may be different. 
Method C configuration MEAs were subjected to various concentrations of IPA namely $1 \%$ (Method D) and 15\% (Method E) in $\mathrm{Ca}^{2+}$ solution and only $15 \%$ isopropanol in DI water (Method F). Figure 9 shows the polarization curves and the power density curves obtained immediately after soaking. A reference MEA performance is also included in the figure. $1 \%$ (Method D) and 15\% (Method E) IPA in $\mathrm{Ca}^{2+}$ solution showed significant performance loss, and there was a dependence on IPA concentration: 15\% IPA in $\mathrm{Ca}^{2+}$ solution showed lower performance compared to $1 \%$ IPA in $\mathrm{Ca}^{2+}$ solution possible due to higher wetting of GDL with larger IPA concentration and subsequent penetration of $\mathrm{Ca}^{2+}$ ion. Maximum power densities for $1 \%$ (Method D) and $15 \%$ (Method E) isopropanol in $\mathrm{Ca}^{2+}$ solution decreased by $37 \%$ and $54 \%$, respectively. However, when the MEA was soaked in a $15 \%$ IPA in DI water solution (Method F), the measured polarization curves and power density curves were similar to $15 \%$ IPA in $\mathrm{Ca}^{2+}$ solution (Method E). As such, IPA itself significantly decreased performance, and it was not easy to distinguish whether IPA facilitated cation transport through the GDL.

To confirm the presence of cations within the CCM, SEM and EDX analyses of the cross section of the MEA contaminated with $15 \%$ IPA in $\mathrm{Ca}^{2+}$ solution were conducted as shown in Fig. 10. Elemental map from EDX clearly shows the presence of $\mathrm{Ca}^{2+}$ inside the CCM, which confirms that IPA sufficiently increases the wettability of the GDL and enables transport of $\mathrm{Ca}^{2+}$ solution through the GDL. Wettability of the GDL plays an important role in the transport of cations to the CCM through the GDL, and high concentrations of IPA as a wetting agent are required to transport cation solutions across the GDL into the CCM. Unfortunately, high fraction of IPA causes performance loss issues not related to cationic contamination. 


\section{Summary and Conclusions}

The effect of GDL in cation contamination was investigated using three different configurations while soaking in a cationic solution, with the major difference being whether the CCM was completely/partially exposed to the cationic solution or fully separated by the GDL and the gasket. It was shown that the hydrophobic nature of the GDL and the MPL acted as a barrier for cationic solution to reach the CCM, which was further verified by using a wetting agent in the cationic solution. Based on this, we hypothesize that commercially available GDLs with MPL will act as a barrier for foreign cations to exit the CCM as well. If a cationic contaminant enters the cell by any means, a wetting agent with sufficiently high concentration will be required to remove the cation from the CCM and consequently from the cell. This finding also suggests that, an air filter with properties similar to the GDL can be used to hinder the transport of cations in liquid phase to the fuel cell.

\section{Acknowledgments}

The authors are grateful for the financial support of the Department of Energy (DOE)-EERE, DE-EE0000467 (University of Hawaii, prime contractor; PI: Jean StPierre).

\section{References}

[1] Collier A, Wang H, Yuan XZ, Zhang J, Wilkinson DP. Degradation of polymer electrolyte membranes. Int J Hydrogen Energy 2006;31:1838-54. 
[2] Cheng X, Shi Z, Glass N, Zhang L, Zhang J, Song D, et al. A review of PEM hydrogen fuel cell contamination: Impacts, mechanisms, and mitigation. J Power Sources 2007;165:739-56.

[3] Li H, Tsay K, Wang H, Shen J, Wu S, Zhang J, et al. Durability of PEM fuel cell cathode in the presence of Fe 3 and Al 3. J Power Sources 2010;195:8089-93.

[4] Sulek M, Adams J, Kaberline S, Ricketts M, Waldecker JR. In situ metal ion contamination and the effects on proton exchange membrane fuel cell performance. J Power Sources 2011;196:8967-72.

[5] Kelly MJ, Fafilek G, Besenhard JO, Kronberger H, Nauer GE. Contaminant absorption and conductivity in polymer electrolyte membranes. J Power Sources 2005;145:249-52.

[6] Hongsirikarn K, Goodwin JG, Greenway S, Creager S. Effect of cations $\left(\mathrm{Na}^{+}, \mathrm{Ca}^{2+}\right.$, $\mathrm{Fe}^{3+}$ ) on the conductivity of a Nafion membrane. J Power Sources 2010;195:721320.

[7] Wang H, Turner JA. The influence of metal ions on the conductivity of Nafion 112 in polymer electrolyte membrane fuel cell. J Power Sources 2008;183:576-80.

[8] Okada T, Nakamura N, Yuasa M, Sekine I. Ion and water transport characteristics in membranes for polymer electrolyte fuel cells containing $\mathrm{H}$ and $\mathrm{Ca} 2$ cations. $\mathrm{J}$ Electrochem Soc 1997;144:2744-50.

[9] Okada T, Xie G, Gorseth O, Kjelstrup S, Nakamura N, Arimura T. Ion and water transport characteristics of Nafion membranes as electrolytes. Electrochim Acta 1998;43:3741-7. 
[10] Okada T, Møller-Holst S, Gorseth O, Kjelstrup S. Transport and equilibrium properties of Nafion ${ }^{\circledR}$ membranes with $\mathrm{H}$ and $\mathrm{Na}$ ions. $\mathrm{J}$ Electroanal Chem 1998;442:137-45.

[11] Okada T, Ayato Y, Yuasa M, Sekine I. The effect of impurity cations on the transport characteristics of perfluorosulfonated ionomer membranes. J Phy Chem B 1999;103:3315-22.

[12] Okada T. Effect of ionic contaminants. In: Vielstich W, Gasteiger HA, Lamm A, Yokokawa H, editors. Handbook of fuel cells - fundamentals, Technology and Applications. New York: John Wiley \& Sons, Ltd; 2010.

[13] Saito M, Arimura N, Hayamizu K, Okada T. Mechanisms of ion and water transport in perfluorosulfonated ionomer membranes for fuel cells. J Phy Chem B 2004;108:16064-70.

[14] Sakai T, Takenaka H, Wakabayashi N, Kawami Y, Torikai E. Gas permeation properties of solid polymer electrolyte (SPE) membranes. J Electrochem Soc 1985;132:1328-32.

[15] Okada T, Ayato Y, Dale J, Yuasa M, Sekine I, Asbjørnsen OA. Oxygen reduction kinetics at platinum electrodes covered with perfluorinated ionomer in the presence of impurity cations $\mathrm{Fe}^{3+}, \mathrm{Ni}^{2+}$ and $\mathrm{Cu}^{2+}$. Phy Chem Chem Phy 2000;2:3255-61.

[16] Durst J, Chatenet M, Maillard F. Impact of metal cations on the electrocatalytic properties of $\mathrm{Pt} / \mathrm{C}$ nanoparticles at multiple phase interfaces. Phy Chem Chem Phy 2012;14:13000-9.

[17] Serincan MF, Pasaogullari U, Molter T. Modeling the cation transport in an operating polymer electrolyte fuel cell (PEFC). Int $\mathbf{J}$ Hydrogen Energy 2010;35:5539-51. 
[18] Uddin MA, Pasaogullari U. Computational Modeling of Foreign Cation Contamination in PEFCs. J Electrochem Soc 2014;161:F1081-8.

[19] Qi J, Wang X, Pasaogullari U, Bonville L, Molter T. Effect of Al3 contaminant on polymer electrolyte fuel cell performance. J Electrochem Soc 2013;160:F916-22.

[20] Pozio A, Silva R, De Francesco M, Giorgi L. Nafion degradation in PEFCs from end plate iron contamination. Electrochim Acta 2003;48:1543-9.

[21] Wang X, Qi J, Ozdemir O, Uddin A, Pasaogullari U, Bonville LJ, et al. $\mathrm{Ca}^{2+}$ as an air impurity in polymer electrolyte membrane fuel cells. J Electrochem Soc 2014;161:F1006-14.

[22] Uddin MA, Wang X, Park J, Pasaogullari U, Bonville L. Distributed effects of calcium ion contaminant on polymer electrolyte fuel cell performance. J Power Sources 2015;296:64-9.

[23] Uddin MA, Qi J, Wang X, Pasaogullari U, Bonville L. Distributed cation contamination from cathode to anode direction in polymer electrolyte fuel cells. Int J Hydrogen Energy 2015;40:13099-105.

[24] Banas CJ, Pasaogullari U. Statistical Analysis of Salt Deposition inside PEFC GDL from X-Ray Tomography. ECS Trans 2015; 69: 511-522.

[25] Uddin MA, Wang X, Qi J, Ozdemir MO, Pasaogullari U, Bonville L, et al. Effect of Chloride on PEFCs in Presence of Various Cations. $\mathrm{J}$ Electrochem Soc 2015;16:F373-9.

[26] Qi J, Wang X, Ozdemir MO, Uddin MA, Bonville L, Pasaogullari U, et al. Effect of cationic contaminants on polymer electrolyte fuel cell performance. J Power Sources 2015;286:18-24. 
[27] Ganesan S, Uddin MA, Park J, Pasaogullari U, Bonville LJ, Molter T. Impact of Cationic Impurities on Low-Pt Loading PEFC Cathodes. ECS Trans 2015;66:19-27.

[28] Park J, Uddin MA, Ganesan S, Pasaogullari U, Bonville LJ, Molter T. Effects on Wetting Agents in Cationic Contamination and Mitigation in PEFCs. ECS Trans 2015;66:91-100.

[29] St-Pierre J. PEMFC contaminant tolerance limit-Foreign cations in ionomers. Int J Hydrogen Energy 2011;36:5527-35. 
Table 1. MEA contamination methods

\begin{tabular}{|c|c|c|c|c|}
\hline Method & Method description & Soaking solution & $\begin{array}{l}\text { Soaking } \\
\text { time }\end{array}$ & $\begin{array}{c}\text { Wetting } \\
\text { agent }\end{array}$ \\
\hline A & $\begin{array}{l}\text { The CCM is in direct contact with } \\
\text { the } \mathrm{Ca}^{2+} \text { solution }\end{array}$ & $\begin{array}{l}0.9 \mathrm{mM} \mathrm{CaSO}_{4}+ \\
29.1 \mathrm{mM} \mathrm{H}_{2} \mathrm{SO}_{4}\end{array}$ & $24 \mathrm{~h}$ & - \\
\hline B & $\begin{array}{l}\text { Portion of the CCM is in direct } \\
\text { contact with the } \mathrm{Ca}^{2+} \text { solution }\end{array}$ & $\begin{array}{l}0.9 \mathrm{mM} \mathrm{CaSO}_{4}+ \\
29.1 \mathrm{mM} \mathrm{H}_{2} \mathrm{SO}_{4}\end{array}$ & $100 \mathrm{~h}$ & - \\
\hline $\mathrm{C}$ & $\begin{array}{l}\text { The CCM is not in direct contact } \\
\text { with the solution being separated by } \\
\text { both the GDL and a gasket }\end{array}$ & $\begin{array}{l}0.9 \mathrm{mM} \mathrm{CaSO}_{4}+ \\
29.1 \mathrm{mM} \mathrm{H}_{2} \mathrm{SO}_{4}\end{array}$ & $100 \mathrm{~h}$ & - \\
\hline $\mathrm{D}$ & Method C with wetting agent & $\begin{array}{l}0.9 \mathrm{mM} \mathrm{CaSO}_{4}+ \\
29.1 \mathrm{mM} \mathrm{H}_{2} \mathrm{SO}_{4}\end{array}$ & $100 \mathrm{~h}$ & $1 \%$ IPA \\
\hline $\mathrm{E}$ & Method C with wetting agent & $\begin{array}{l}0.9 \mathrm{mM} \mathrm{CaSO}_{4}+ \\
29.1 \mathrm{mM} \mathrm{H}_{2} \mathrm{SO}_{4}\end{array}$ & $100 \mathrm{~h}$ & $15 \%$ IPA \\
\hline $\mathrm{F}$ & Method $\mathrm{C}$ with wetting agent & $15 \%$ IPA & $100 \mathrm{~h}$ & - \\
\hline
\end{tabular}


Table 1. MEA contamination methods

\begin{tabular}{|c|c|c|c|c|}
\hline Method & Method description & Soaking solution & $\begin{array}{l}\text { Soaking } \\
\text { time }\end{array}$ & $\begin{array}{l}\text { Wetting } \\
\text { agent }\end{array}$ \\
\hline A & $\begin{array}{l}\text { The CCM is in direct contact with } \\
\text { the } \mathrm{Ca}^{2+} \text { solution }\end{array}$ & $\begin{array}{l}0.9 \mathrm{mM} \mathrm{CaSO}_{4}+ \\
29.1 \mathrm{mM} \mathrm{H}_{2} \mathrm{SO}_{4}\end{array}$ & $24 \mathrm{~h}$ & - \\
\hline B & $\begin{array}{l}\text { Portion of the } \mathrm{CCM} \text { is in direct } \\
\text { contact with the } \mathrm{Ca}^{2+} \text { solution }\end{array}$ & $\begin{array}{l}0.9 \mathrm{mM} \mathrm{CaSO}_{4}+ \\
29.1 \mathrm{mM} \mathrm{H}_{2} \mathrm{SO}_{4}\end{array}$ & $100 \mathrm{~h}$ & - \\
\hline $\mathrm{C}$ & $\begin{array}{c}\text { The CCM is not in direct contact } \\
\text { with the solution being separated by } \\
\text { both the GDL and a gasket }\end{array}$ & $\begin{array}{l}0.9 \mathrm{mM} \mathrm{CaSO}_{4}+ \\
29.1 \mathrm{mM} \mathrm{H}_{2} \mathrm{SO}_{4}\end{array}$ & $100 \mathrm{~h}$ & - \\
\hline $\mathrm{D}$ & Method $\mathrm{C}$ with wetting agent & $\begin{array}{l}0.9 \mathrm{mM} \mathrm{CaSO}_{4}+ \\
29.1 \mathrm{mM} \mathrm{H}_{2} \mathrm{SO}_{4}\end{array}$ & $100 \mathrm{~h}$ & $1 \%$ IPA \\
\hline $\mathrm{E}$ & Method $\mathrm{C}$ with wetting agent & $\begin{array}{l}0.9 \mathrm{mM} \mathrm{CaSO}_{4}+ \\
29.1 \mathrm{mM} \mathrm{H}_{2} \mathrm{SO}_{4}\end{array}$ & $100 \mathrm{~h}$ & $15 \%$ IPA \\
\hline $\mathrm{F}$ & Method C with wetting agent & $15 \%$ IPA & $100 \mathrm{~h}$ & - \\
\hline
\end{tabular}




\section{Figure captions}

Fig. 1 - MEA contamination method: (a) A: The CCM is in direct contact with the $\mathrm{Ca}^{2+}$ solution. (b) B: The CCM is only in direct contact with the $\mathrm{Ca}^{2+}$ solution only at its periphery because the solution does not wet the GDL. (c) $\mathrm{C}$ : The CCM is not in direct contact with the solution being separated by both the GDL and a gasket.

Fig. 2 - (a) Polarization curves and (b) power density curves of a common baseline and others obtained after different $\mathrm{Ca}^{2+}$ exposure methods shown in Fig. 1 and Table 1. Operating conditions: cell temperature $80{ }^{\circ} \mathrm{C}$, anode/cathode: $100 / 75 \%$ relative humidity, 0/0 kPag back pressure, 2/2 stoichiometry (200/200 sccm minimum flow).

Fig. 3 - SEM image and EDX result of CCM cross section after soaking MEA in contamination method $\mathrm{B}$ as described in Fig. 1 and Table 1. EDX result shows the presence of calcium inside the CCM.

Fig. 4 - (a) GDL hydrophilicity parameter definition: sessile drop showing the characteristic dimensions, L1 (major dia), L2 (minor dia) and ratio (L2/L1) represents the wettability of the GDL, and comparison between different wetting agent (1\% of Triton$\mathrm{X}$ (Tri), isopropanol (IPA), ethanol, and methanol) and their ability to facilitate GDL wetting (b) GDL side and (c)MPL side.

Fig. 5 - Effect of Triton-X (Tri) concentration on the GDL hydrophilicity parameter. (ab) wettability of both side of the GDL for $1 \%-20 \%$ of Triton-X and (c) image after soaking MEA in 5\% Tri for 24 hours where it shows the detachment of the catalyst layer from the CCM.

Fig. 6 - Effect of isopropanol (IPA) concentration on the GDL hydrophilicity parameter. (a-b) wettability of both sides of the GDL for $1 \%-35 \%$ of IPA and (c) sessile drop of $25 \%$ IPA on GDL. 
Fig. 7 - Status of CCM after soaking in $0.9 \mathrm{mM} \mathrm{CaSO}_{4}$ and $29.1 \mathrm{mM} \mathrm{H}_{2} \mathrm{SO}_{4}$ with various fraction of isopropanol (IPA) for 24 hours.

Fig. 8 - Wettability of the dry MPL after soaking in $0.9 \mathrm{mM} \mathrm{CaSO}_{4}$ and $29.1 \mathrm{mM} \mathrm{H}_{2} \mathrm{SO}_{4}$ with $15 \%$ isopropanol for 24 hours at $80^{\circ} \mathrm{C}$.

Fig. 9 - (a) Polarization curves and (b) power density curves of a common baseline and others obtained after soaking in various percentages of isopropanol namely $1 \%$ (Method D) and $15 \%$ (Method $\mathrm{E}$ ) in $\mathrm{Ca}^{2+}$ solution and $15 \%$ isopropanol in deionized water (Method F) as described in Fig. 1 and Table 1. Operating conditions: $80^{\circ} \mathrm{C}$, anode/cathode: 100/75\% relative humidity, 0/0 kPag back pressure, 2/2 stoichiometry (200/200 sccm minimum flow).

Fig. 10 - SEM image and EDX result of CCM cross section after soaking MEA in contamination method $\mathrm{C}$ with $15 \%$ isopropanol in cation solution. 
Fig. 1

(a)

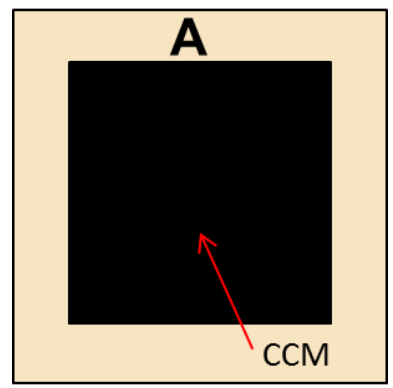

(b)

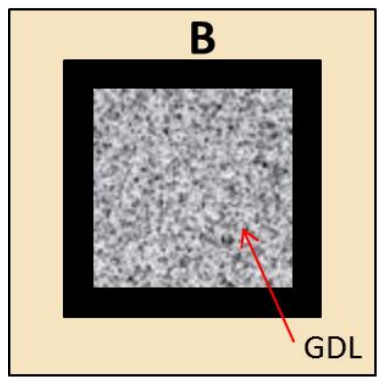

(c)

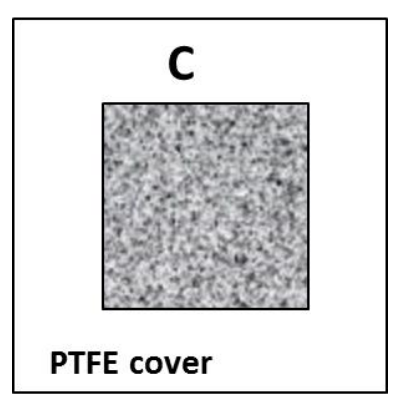

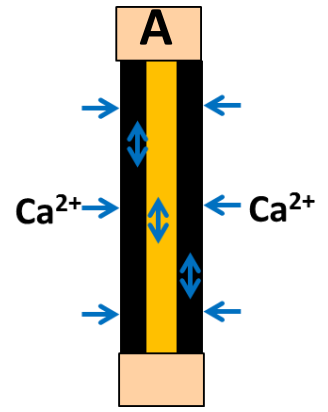
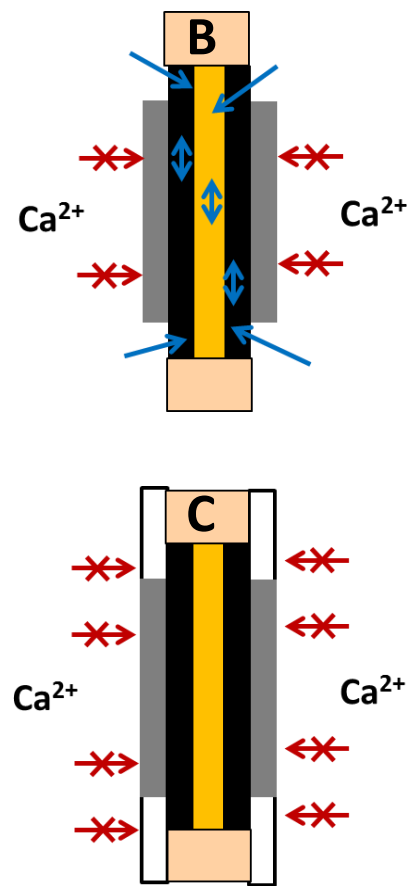
Fig. 2
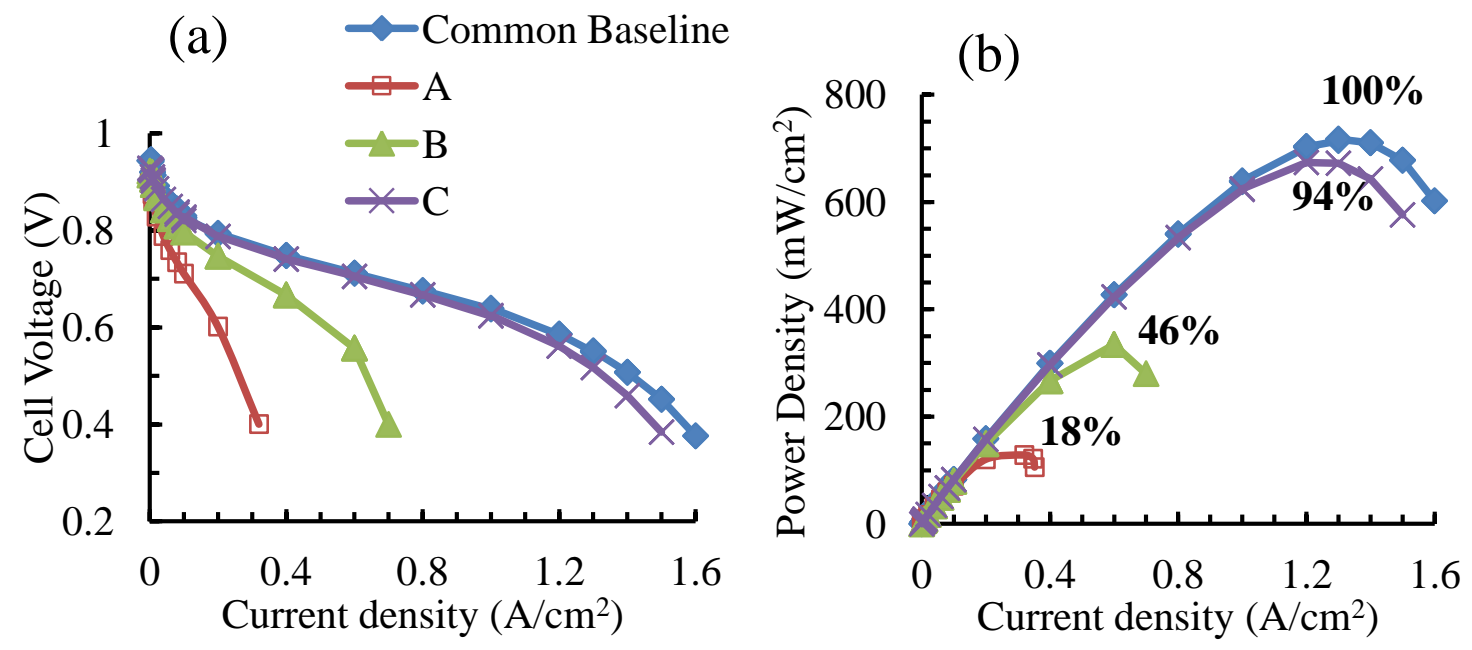
Fig. 3.

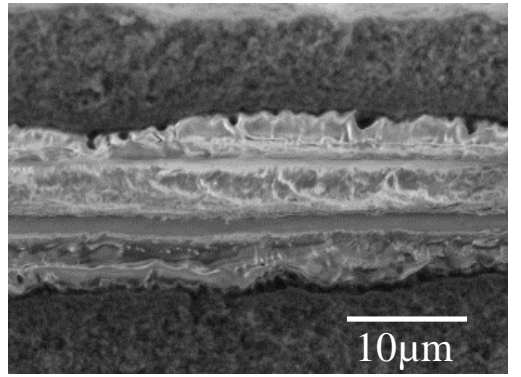

C $\mathrm{Ka}$

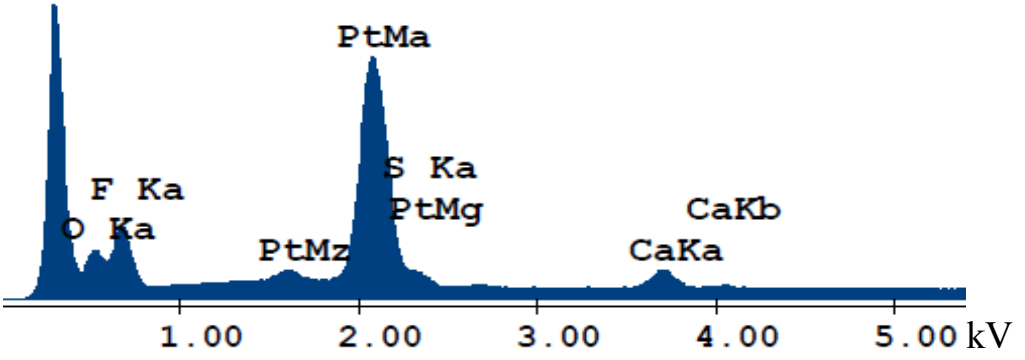


Fig. 4

(a)

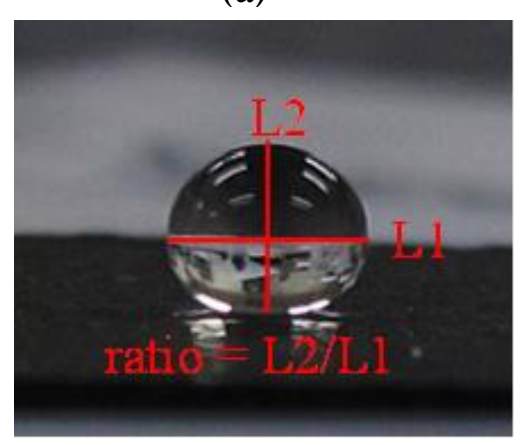

(b) GDL side

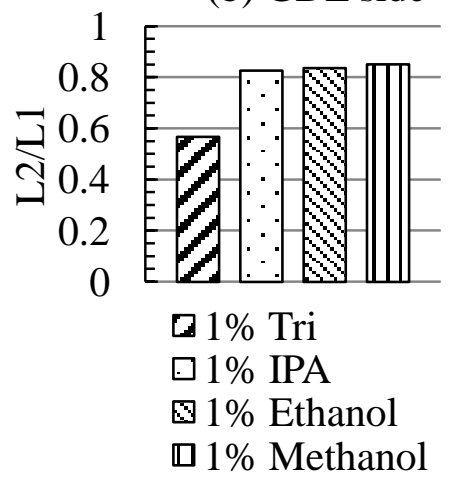

(c) MPL side

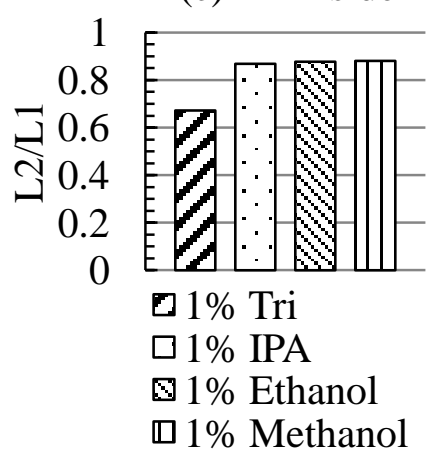


Fig. 5
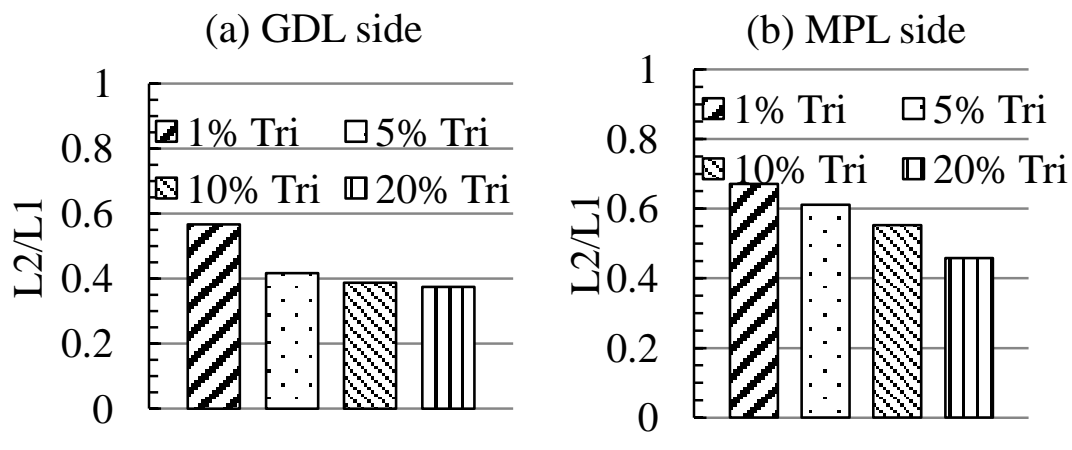

(c) After soaking

MEA in 5\% Tri

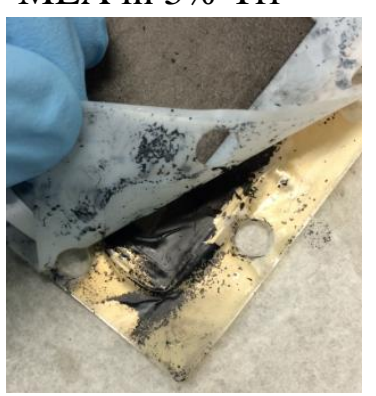


Fig. 6

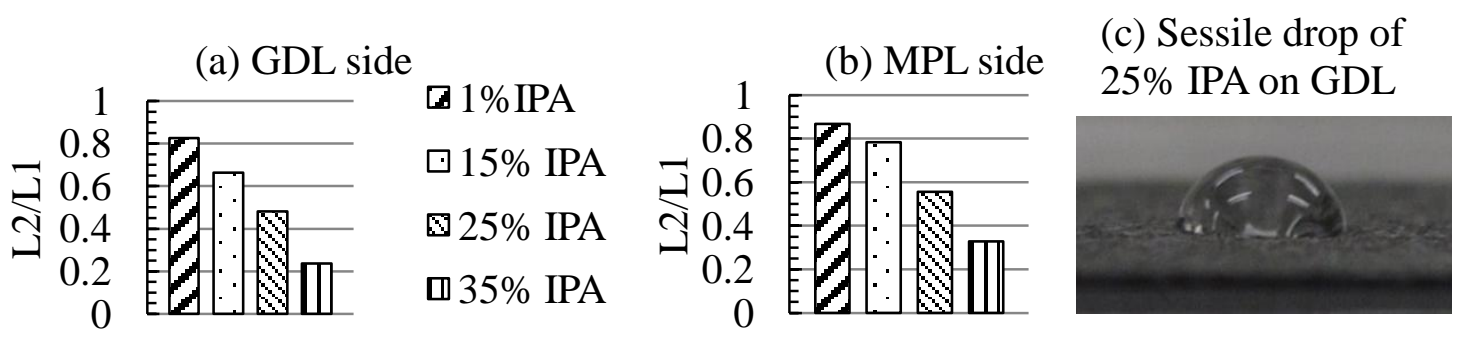


Fig. 7
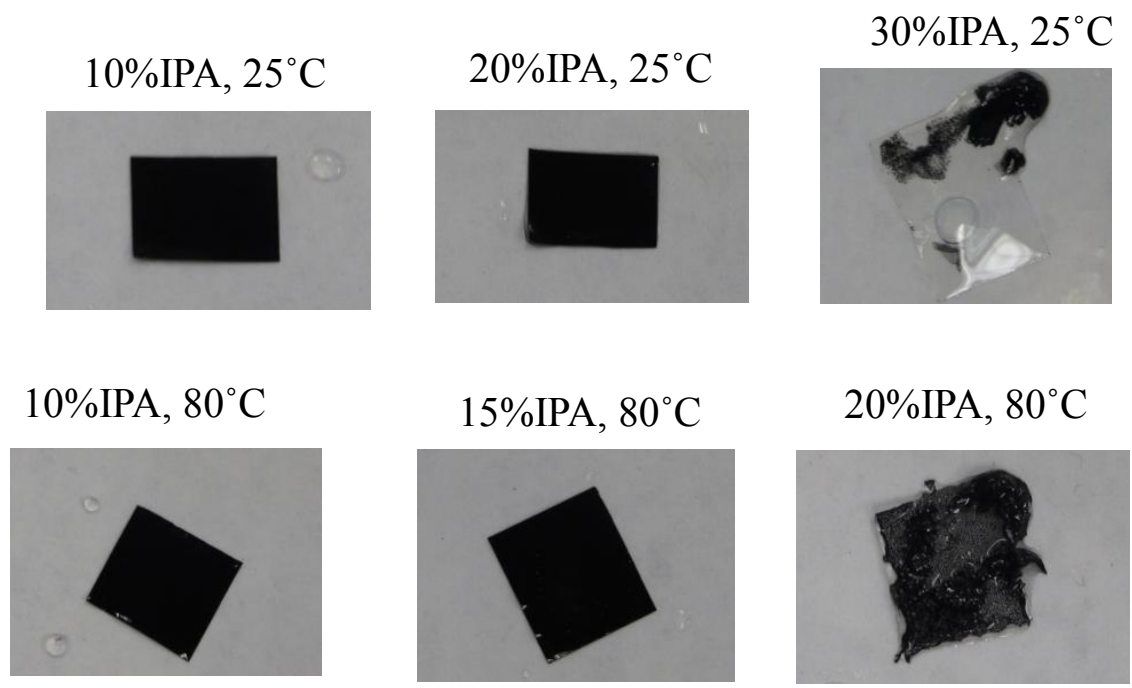
Fig. 8

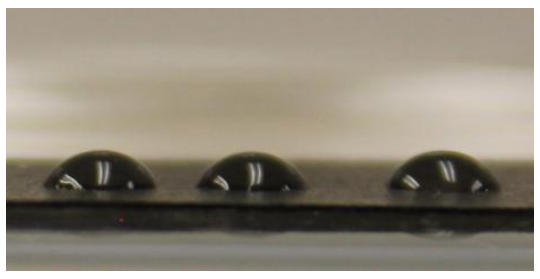


Fig. 9

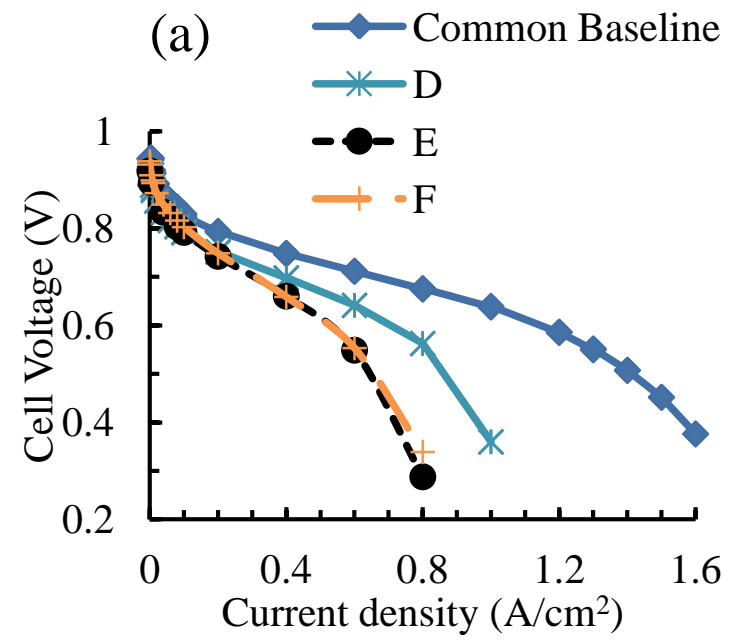

(b)

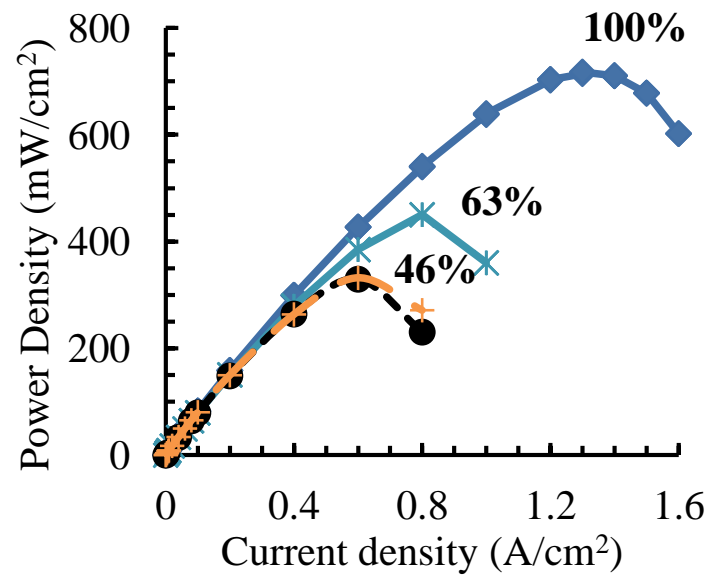


Fig. 10

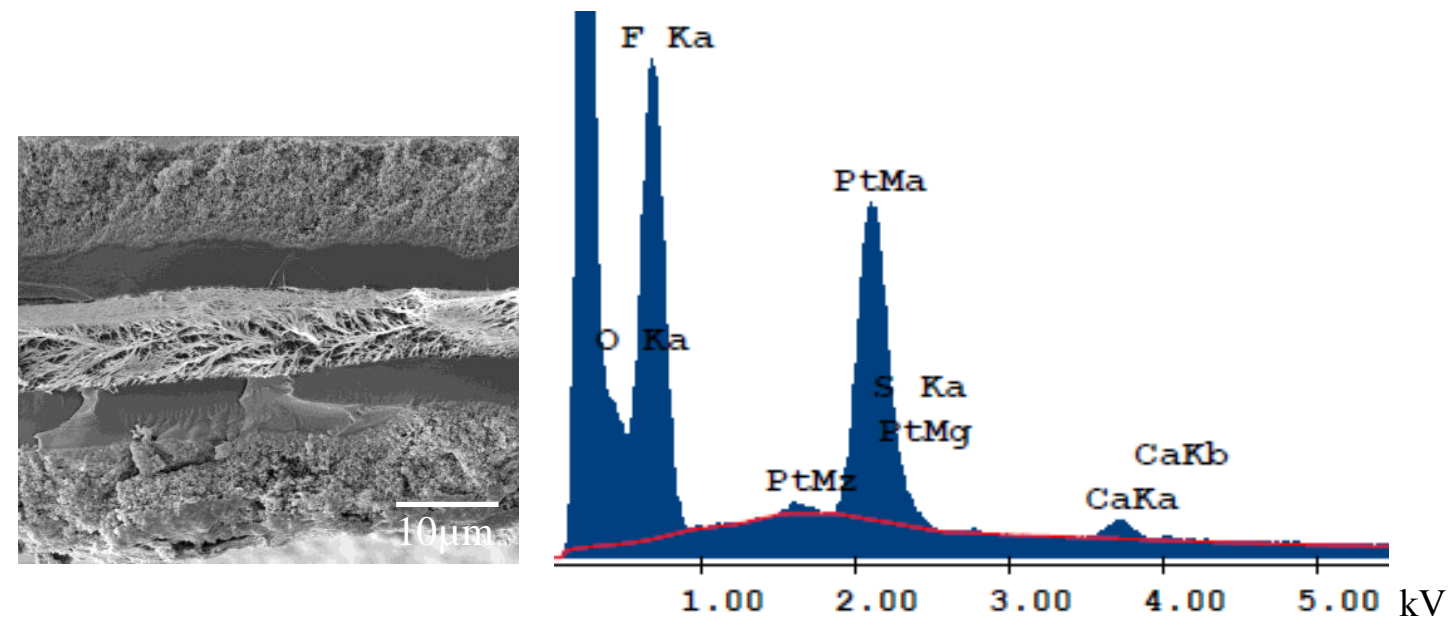

